\title{
'Israel' in biblical and Christological terms
}

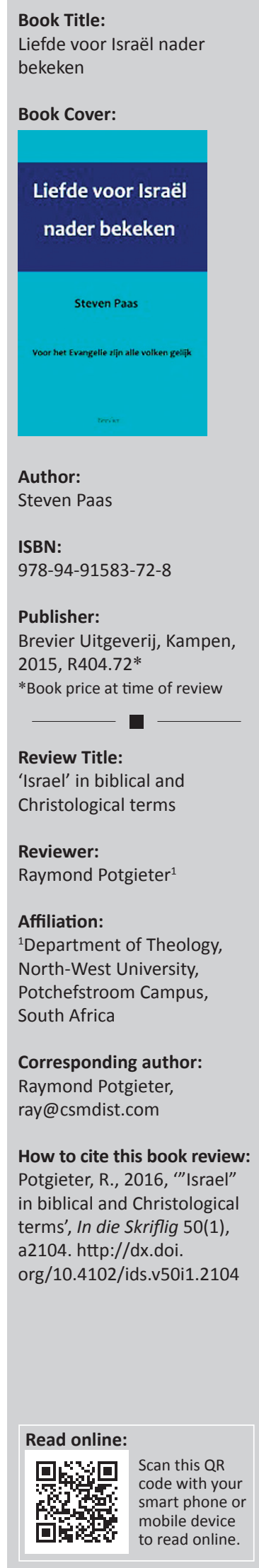

This book deals with an essential question: Is the gospel sufficient for Jew and Gentile? The answer, deceptively simple, comes with huge ramifications. One quickly realises that for Paas there is not one version of the gospel for Jew and another for non-Jew (Gentile). Extrapolated, this means that no nation enjoys privileged status in spite of popular expressions claiming love and sympathy for Jews and claims of the spiritual and New Testament significances of the founding of the Jewish nation in 1948 (p. 24). These claims are basically lumped under what Paas calls 'religious or ideological' notions (p. 18), generally closely related to a variety of eschatological views (p. 7). These major on, among others, the horrors of the holocaust and the 'Jewishness of Jesus' as bond between Christians and Israel (p. 14-15). Such views tend to romanticise Israel, elevating it above other nations (p. 20). It impacts the approach of missionary endeavours to the Jews, seeks to redefine the reformational concept of church, the traditional understanding of the covenant of grace (ch. 6) and the Christocentric nature of the Bible (p. 24). In fact, Paas says insightfully, an overly sympathetic view of Judaism implies a questioning of Christian truth (p. 15). For that reason, the church needs to resort to clear thinking. Israel needs to be identified in biblical and Christological terms for present evaluation and understanding. Which is what this book endeavours to achieve.

A brief word about the content of the book: Paas resorts to various polar opposites such as 'anti-Judaism' and 'anti-semitism'; 'Israel' and 'Jews'; 'ordinary' or 'peculiar'; 'inclusivity' and 'exclusivity' and so on to develop his argument. This is enormously helpful as these definitions clarify the common vocabulary Christians tend to resort to when speaking about Israel thus aiding meaningful conversation and understanding.

Historically covenant Jews were the children of Abraham. Whereas God's children now include Jew and Gentile, who find their spiritual genesis in the Jew, Jesus the Messiah and share in his kingdom (pp. 146-147, 166). That is the gospel of salvation seen in its historic and traditional sense. Salvation is not from the Jews, it is from the Jew called Jesus (p. 28) and for that reason expresses the Christological uniqueness of the covenant of grace (p. 30) attested to in the 'book of Christ' (NT) as opposed to the 'book of Israel' (OT) (p. 55). This is an important distinction. Jesus is the promise for all nations (p. 159). Historically this view expressed itself variously. Because of Judaism's rejection of God's Son, Martin Luther made some strong statements, that taken out of context potentially form anti-semitism (chs. 3-4; cf. pp. 105, 119, 189). However, ethnic differences are not neglected. This is important for the church to understand. Ethnicity does not advantage or disadvantage any people or person, no matter what their historical relevance in salvation history are.

Paas adds a valuable reminder that anti-Semitism 'Jodenhaat' does not equate to anti-Judaism (p. 15 \& ch. 5:115-145). He shows how Luther's views and some of his strong utterances pertaining to Jews were twisted by the Nazis (p. 59). To that end almost a quarter of the book (chs. 2-4) is spent on Luther's views, which tends to be somewhat repetitive and verbose. What is clear is that because Luther's Christocentric perspective impacted the Reformation it also influenced traditional and historic interpretations pertaining to the Jews. Interestingly, Paas also gives some insight into Jewish reactions to the Reformation, such as Luther's anti-Jewish rules of 1543. Luther, for instance believed that civic authorities could be called upon to deal with unbelief and false worship (pp. 92-93). This was not a focus on Jews as an ethnic group but expressed concern to address error (p. 98) such as deviating from the gospel.

There is also the interesting polar distinction between Israel and Jew. The former reflects God's covenantal expectations which focus on the Christ of revelation history. The latter relates to the nation which broke the covenant and drifted away from the true God (p. 98). Consequently Jews lost their right to differentiation from other nations (p. 99). For that reason Paas questions the use

Copyright: (C 2016. The Authors. Licensee: AOSIS. This work is licensed under the Creative Commons Attribution License. 
of the phrase 'people of God' applied to the Jews (p. 168). This could be construed as being controversial as he does not equate present day Israel to that of the Old Testament Israel. But Paas carefully substantiates his claim. He does that on the lack of revelatory grounds (p. 168) and the lack of validation for replacement theology in Luther (cf. p. 174ff.). Whatever utterances made about Jews, present or past, Paas is convinced that Luther's passion for salvation of all persons and the Word of God (p. 105) should be the same unerring guide in the third millennium.

Paas concludes his book with an evangelical emphasis (ch. 8). The gospel penetrates the differentiation between antisemitism and anti-Judaism. While the former relates to nationalism and implied racism the latter in gospel conversation is based on the love of Christ and does not reject the person but addresses unbelief and belief (also read system) held to by that person (p. 116). New Testament scholars are cautioned not to neglect respect and love for Jews in their interpretation of the Bible which may sometimes be seen to be racial (p. 142).

This book seems to have been written as a corrective to Paas' previous book, Israëlvisies in beweging (2014), which in the opinion of some researchers had anti-Semitic undertones. This present book should, however, correct any such misunderstanding. Paas's love for the Jews, indeed for all nations, is expressed in New Testament gospel terms and clearly reflects the love of God for both Jew and Gentile. The book could have added some reflection on suffering although its absence does not substantially detract from the overall message. Some additional engagement with prophecy and apocalyptic literature could be considered in its future revision. But finally true love for Israel translates in sharing the gospel. This book is recommended for all who want to engage in serious conversation about the relevance of Israel in the present day. 